\title{
Reseña
}

\section{Frend en el cine: de lo sublime a lo ridículo}

Eduardo Laso y Juan Jorge Michel Fariña| 2019

\section{Nazareno Guerra* y Paula Mastandrea**}

Universidad de Buenos Aires, Argentina

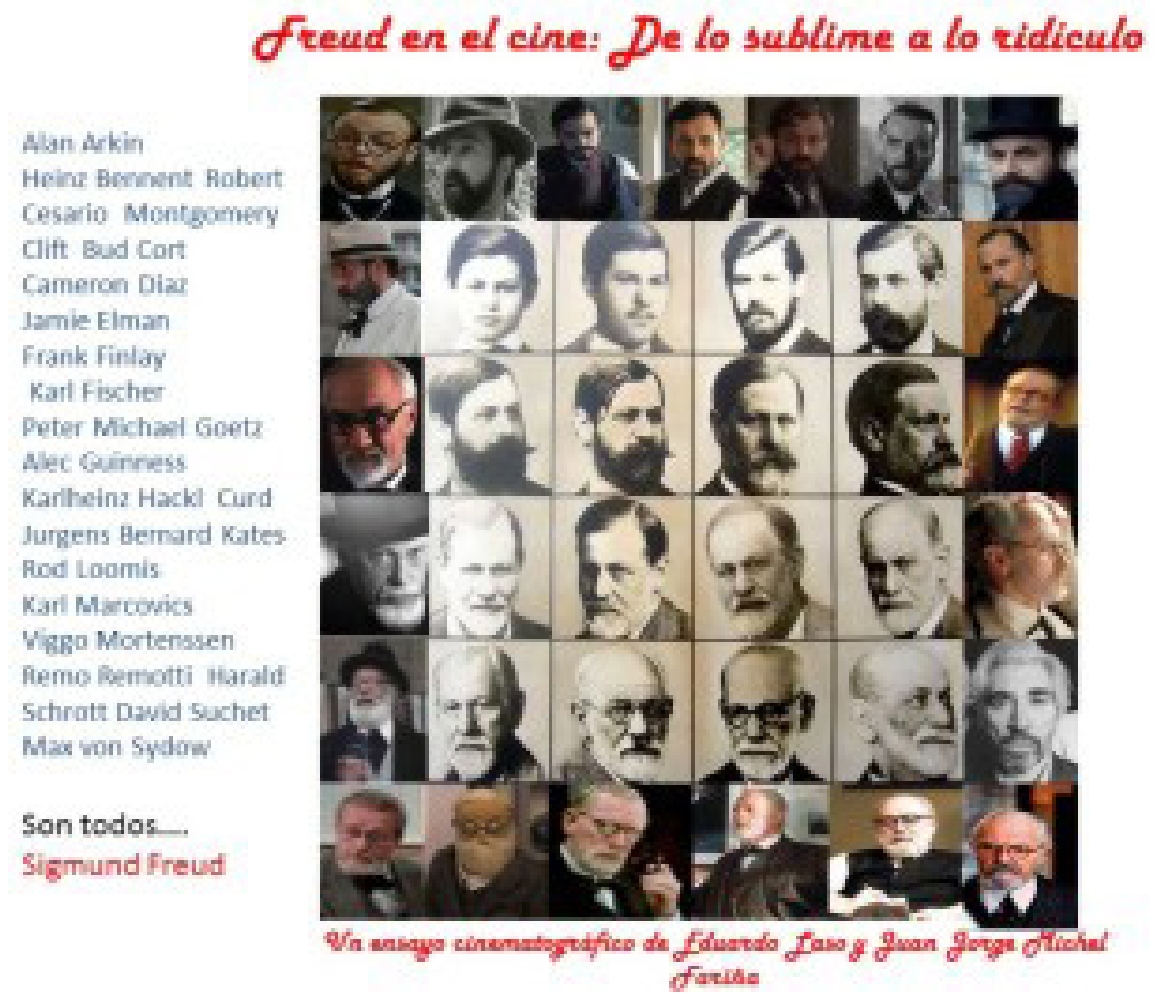

Cine y Psicoanálisis: encuentros y desencuentros

Es ampliamente conocida la coincidencia histórica existente entre el surgimiento del Psicoanálisis y el del Cine, ambos hacia fines del siglo XIX, de la mano de "Estudios sobre la histeria" (Freud, 1895) y de la primera proyección pública del cinematógrafo a cargo de los hermanos Lumiére, en el mismo año. Sin embargo, Freud asiste por primera vez al cine en un viaje que realiza a Nueva York, en 1909, muchos años después del evento a cargo de los conocidos hermanos, y ca- racteriza a la obra audiovisual como un "espectáculo de feria".

Esta anécdota, junto con otros datos históricos interesantes, funcionan como punto de partida para el planteo del film Frend en el cine: de lo sublime a lo ridículo (Laso y Michel Fariña, 2019). En él sus productores buscan retomar este vínculo entre ambas disciplinas para responder al interrogante acerca de cómo el cine ha representado a Sigmund Freud a lo largo de la historia, para así analizar el modo en que dichas representaciones proponen, indirectamente, una posición sobre el Psicoanálisis en la cultura. 
Como se señala en el film, el recurrente desinterés que Freud expresó por el cine no fue correspondido por la industria audiovisual, que ha utilizado una y otra vez su imagen para representarlo. Por este motivo, la obra realiza un recorrido por más de veinte filmes y series televisivas que tienen en común haber representado a la icónica figura de Sigmund Freud.

La película entonces se plantea la siguiente empresa: ¿cómo organizar el material filmográfico disponible? ¿De qué manera otorgar un orden a las distintas representaciones audiovisuales que se han otorgado al padre del Psicoanálisis? Estas preguntas pueden pensarse como la primera dificultad metodológica con la que se encuentra esta realización audiovisual.

\section{El cine-ensayo como apuesta metodológica}

Tal como lo señala Machado (2010), el filme-ensayo implica un proceso de búsqueda e indagación conceptual. Lo que interesa en este tipo de producciones es lo que el cineasta hace con los materiales con los que cuenta -imágenes captadas por cámaras, diseñadas o generadas en una computadora, materiales sonoros, etc.-, cómo construye con ellos una reflexión rica sobre el mundo, cómo transforma todos esos materiales inertes y en bruto en experiencia de vida y pensamiento.

En esta línea, Provitina (2014) afirma que "el ensayista debe crear la estructura que hará posible la aplicación de sus ideas" (p. 42). El planteo argumentativo del ensayo cinematográfico desarrollado por Laso y Michel Fariña consiste en organizar el material relevado "de lo sublime a lo ridículo", contrastando obras de una gran rigurosidad histórica y de realización, como Frend: The Secret Passion (Houston, 1962), con otras realizaciones que resultan más banales y carentes de profundidad, como por ejemplo The Secret Diary of Sigmund Frend (Greene, 1984).

La originalidad de esta película no se basa en realizar una enumeración cuantitativa sobre cómo Freud ha sido retratado en el cine, sino en organizar el material a partir de categorías que le permitan al espectador aprehender conceptualmente las diversas maneras en las que éste ha sido interpretado en la pantalla. En lugar de otorgar un formato cerrado de catalogación de archivo de los films y series en cuestión, la película se divide en seis capítulos que expresan un modo posible de organizar el material relevado (así como también permite, a partir de ello, conceptualizar las potenciales futuras caracterizaciones que se realicen sobre Freud):

- Capítulo I: "Freud frente al cine"

- Capítulo II: "Retratos de Freud"

- Capítulo III: "Filmando la leyenda negra"

- Capítulo IV: "Fantasías sobre Freud"

- Capítulo V: "Freud en broma"

- Epílogo: "Freud por Freud"

Laso (2018) ha estudiado las tres modalidades para el visionado y la apreciación de una obra cinematográfica señaladas por el filósofo Alain Badiou: el juicio indistinto -en el cual se produce una evaluación del film en base a si la experiencia de su visionado fue agradable o desagradable-; el juicio diacrónico -que apunta al conocimiento acerca de la película, el director y la historia del cine, midiendo el valor estético de la producción-; y, finalmente, el juicio axiomático -que refiere a la posibilidad de pensar el film en sí mismo, en tanto objeto estético que vehiculiza una idea y abre a la pregunta por sus efectos a nivel del pensamiento. En este sentido, Frend en el cine: de lo sublime a lo ridículo se aparta del juicio moral, que calificaría a los 36 films que se observan a lo largo de la obra como buenas o malas producciones, para retomar lo que la modalidad del juicio axiomático propone: centrarse en el problema de si el film es justo respecto de lo que intenta transmitir, en este caso, acerca del psicoanálisis y su fundador. La presente obra audiovisual escapa al planteo desde una perspectiva estanca de Freud y se enfoca en el movimiento social que se ha generado alrededor de su figura, para trabajar los diversos modos en que esa conmoción ha sido asimilada al momento de realizar obras audiovisuales sobre él.

Por otro lado, existe una segunda cuestión metodológica a destacar, ya que el film en cuestión se trata de una adaptación audiovisual basada en una serie de pasajes del libro de Laso (2018) "El ojo maravilloso. (Des) encuentros entre psicoanálisis y cine”, fruto de la rigurosa investigación del autor sobre esta temática.

Este paso de lo escrito a la imagen representa un nuevo desafío que está solventado en el film con un montaje dinámico, acompañado de una banda sonora destacable, que hacen del visionado una experiencia enriquecedora y gratificante. Esta tarea no es menor, y representa quizás la mayor dificultad a nivel de guión, ya que supone narrar de forma comprensible para cualquier espectador, un material que ha sido trabajado durante incontables horas de visionado y conceptualización. Ese esfuerzo es 
finalmente llevado a buen puerto, y se puede percibir en el producto final, tanto a través del ritmo dinámico de la voz en off, como también en el tono bien sostenido y argumentado del film.

A modo de conclusión, es interesante señalar que en el 2019 se cumplen ochenta años de la muerte de Freud y, tal como lo demuestra el film, su figura, que devino ícono cultural, continúa vigente. A pesar de las críticas recibidas, el Psicoanálisis y su fundador logran siempre encontrar los resquicios necesarios para manifestarse ante el espectador, tanto en las obras más logradas y curadas a nivel cinematográfico, como en las banalizaciones audiovisuales más burdas y superficiales que se hayan llevado adelante sobre el tema. El resultado del trabajo de Laso y Michel Fariña es una pieza sumamente interesante, tanto para su uso pedagógico en ámbitos académicos, como también para el disfrute de todo aquel que desee adentrarse en los encuentros y desencuentros entre el cine y el Psicoanálisis.

\section{Referencias}

Laso, E. (2017) El ojo maravilloso. (Des)encuentros entre psicoanálisis y cine. Buenos Aires: Ediciones Rojo

Machado, A. (2010). “El filme-ensayo”. En laFuga, 11. [Fecha de consulta: 2019/22/02] Disponible en: http://2016.lafuga.cl/el-filme-ensayo/409

Provitina, G. (2014). El cine-ensayo. La mirada que piensa. Buenos Aires: La marca editora. 